\title{
Papers
}

\section{Antioxidant supplementation for the prevention of kwashiorkor in Malawian children: randomised, double blind, placebo controlled trial}

Heather Ciliberto, Michael Ciliberto, André Briend, Per Ashorn, Dennis Bier, Mark Manary

\begin{abstract}
Objective To evaluate the efficacy of antioxidant supplementation in preventing kwashiorkor in a population of Malawian children at high risk of developing kwashiorkor. Design Prospective, double blind, placebo controlled trial randomised by household.

Setting 8 villages in rural southern Malawi.

Participants 2372 children in 2156 households aged 1-4 years were enrolled; 2332 completed the trial.

Intervention Daily supplementation with an antioxidant powder containing riboflavin, vitamin E, selenium, and $\mathrm{N}$-acetylcysteine in a dose that provided about three times the recommended dietary allowance of each nutrient or placebo for 20 weeks.

Main outcome measures The primary outcome was the incidence of oedema. Secondary outcomes were the rates of change for weight and length and the number of days of infectious symptoms.

Results 62 children developed kwashiorkor (defined by the presence of oedema); 39/1184 (3.3\%) were in the antioxidant group and 23/1188 (1.9\%) were in the placebo group (relative risk $1.70,95 \%$ confidence interval 0.98 to 2.42 ). The two groups did not differ in rates of weight or height gain. Children who received antioxidant supplementation did not experience less fever, cough, or diarrhoea.

Conclusions Antioxidant supplementation at the dose provided did not prevent the onset of kwashiorkor. This finding does not support the hypothesis that depletion of vitamin $\mathrm{E}$, selenium, cysteine, or riboflavin has a role in the development of kwashiorkor.
\end{abstract}

\section{Introduction}

Kwashiorkor is a form of severe childhood malnutrition defined by oedema and characterised by anorexia, irritability, ulcerating dermatosis, and fatty infiltration of the liver. ${ }^{12}$ The hypothesis that kwashiorkor is a consequence of dietary protein deficiency and hypoalbuminemia has been advanced widely. ${ }^{3}$ However, this hypothesis has been challenged by data showing that oedema resolves before serum albumin concentrations change, ${ }^{4}$ children with kwashiorkor do not ingest any less protein than children with marasmus, ${ }^{5}$ and oedema dissipates while the children are being fed a low protein diet. ${ }^{6}$

Golden and Ramdath proposed that kwashiorkor results from an imbalance between the production of free radicals and their safe disposal. ${ }^{7}$ This theory is supported by the observations that blood concentrations of vitamin $\mathrm{E}$ derivatives, glutathione, and red cell antioxidant enzymes are lower in children with kwashiorkor than in marasmic children. ${ }^{8-10}$ There is biochemical evidence of excessive lipid peroxidation in kwashiorkor, ${ }^{11}$ as well as excessive quantities of oxidised amino acids. ${ }^{12}$ In a small clinical trial, the administration of $\mathrm{N}$-acetylcysteine, a glutathione precursor, resulted in more rapid resolution of oedema in kwashiorkor. ${ }^{13}$ These associations between oxidative stress and kwashiorkor indicate that antioxidant depletion may cause kwashiorkor, and the onset of kwashiorkor may therefore be prevented with antioxidant supplementation.

Malawi is a rural country in Africa where $56 \%$ of childhood deaths are attributed to malnutrition and kwashiorkor is the predominant form of severe malnutrition. A large population survey of more than 25000 children conducted in 1994 found the prevalence of kwashiorkor to be $2.5 \%$ in healthy children aged 1-3 years. ${ }^{14}$

This study tested the hypothesis that antioxidant supplementation would prevent kwashiorkor in children in Malawi.

\section{Methods}

We conducted our study from November 2003 to March 2004 in eight villages in the Machinga district of southern Malawi. We chose this district because it was found to have the highest prevalence of kwashiorkor in southern Malawi. ${ }^{14}$ The habitual diet of people in this region is based on maize and is supplemented with fish. Most villagers are subsistence farmers, but they have difficulties growing crops in the sandy soil surrounding the lake. About half of the villagers have access to a source of clean water. Almost everyone in this area lives in mud huts. Health care in these villages is provided mainly by health surveillance assistants, government employees with one year of healthcare training in first aid and simple health maintenance. The nearest health centre is at least $40 \mathrm{~km}$ from the villages.

\section{Participants}

Enrolment was open to all children aged 12-48 months who did not have any severe chronic illness and were not oedematous at the time of enrolment. The study was scheduled to coincide with the rainy season, just before the annual harvest, when children are most likely to develop kwashiorkor. We enrolled children from 3 November to 11 November 2003 and followed them for 20 weeks. All carers gave written and verbal informed consent before enrolment. Carers were able to cease participation at any point in person or by refraining from attending their scheduled follow-up visits. 


\section{Study design}

The experimental design was a double blind, placebo controlled trial, randomised by household, in accordance with the European Commission's guidelines for good clinical practice. ${ }^{15}$ The trial is reported in accordance with the CONSORT guidelines for clustered randomised trials. ${ }^{16}$

On enrolment, the carer of the participating child was questioned about demographic data. The children were checked for oedema and had their height, weight, and circumference of their middle upper arm measured. We recorded these data on a numbered card that had been marked with one of eight letters corresponding to the letters on placebo or active powder bottles. Four of the letters corresponded to a placebo and four to an antioxidant formulation. The carer received an appointment card with their child's study number written on it for presentation at follow-up. We assigned the letter designating the type of powder on each data card prospectively to that data card by using a computerised random number generator blocked in groups of 200. All investigators and caretakers were blind as to which letters were placebo and which contained antioxidants. Siblings received data cards with the same letter to avoid confusion by the carer about which type of powder each child received. On enrolment, we instructed carers how to use the powder and reminded them periodically at follow-up visits. We instructed them to place one scoop of powder into a small plastic cup every day, which was provided for them. They were then told to add approximately $30 \mathrm{ml}$ of water or just enough to dissolve the powder with vigorous agitation. Powder bottles contained a week's supply and went to carers at enrolment and then every four weeks.

The intervention group received a citrus flavoured powder containing $1.8 \mathrm{mg}$ riboflavin, $23 \mathrm{mg}$ Vitamin $\mathrm{E}$ (d- $\alpha$ tocopheryl acetate), $55 \mu \mathrm{g}$ selenium (sodium selenate), and $300 \mathrm{mg}$ $\mathrm{N}$-acetylcysteine per $6 \mathrm{~g}$ (one measuring scoop). The dose of each of the antioxidants was about three times the recommended dietary allowance for children aged $1-3$ years. ${ }^{17}{ }^{18}$ Riboflavin was added to the antioxidant supplement because it is necessary for the reduction of glutathione. The control group received an identical looking, citrus flavoured powder with no active ingredients. In preliminary trials, all children in this age group found the drink acceptable $(n=300)$. Both the placebo and antioxidant powders were developed and produced for the study by Nutriset (Malaunay, France).

Subjects returned for follow-up with the study team (two investigators and two senior nurses) to a central meeting point in their village every two weeks for 20 weeks. The study team recorded presence of oedema and any history of fever, cough, or diarrhoea in the preceding two weeks at every visit. Mothers were asked if the child had a rash or vomiting to monitor for an adverse reaction. We recorded the children's weight and circumference of their middle upper arm at every other visit. We measured height three times at enrolment and three times at each child's last visit and used the average of the three recorded heights in our analysis. Before enrolment, study investigators and senior project nurses received training in an inpatient nutritional unit to assess oedema. During the study, a study investigator assessed oedema by compressing the skin over both of the child's fourth metatarsal bones with a firm finger for 10 seconds and looking for evidence of pitting. All children who were found by an investigator to have oedema also had oedema checked independently by a senior project nurse.

If both a senior project nurse and an investigator judged a child to have oedema, a diagnosis of kwashiorkor was made and the child was removed from the study. Depending on the clinical condition of the oedematous child, he or she was either brought to the nearest nutritional rehabilitation unit for standard treatment or offered home based therapy with ready to use therapeutic food that has been shown to be effective in treating children with kwashiorkor without anorexia or severe infectious symptoms. $^{19}$

Health surveillance assistants residing in the participating villages encouraged participation and compliance with the study protocol and were available to help mothers if any concerns arose about the powder.

A subset of the participants gave urine specimens to be checked for compliance. Urine samples came from 21 children who developed oedema in February and March 2004 and from 24 randomly selected non-oedematous children. A laboratory technician checked urine for ultraviolet fluorescence indicating the presence of riboflavin. ${ }^{20}$

The primary outcome of this study was the incidence of oedema. Secondary outcomes were the rates of change in weight; gain in circumference of the middle upper arm and length of the arm; and the number of days of fever, cough, and diarrhoea.

\section{Statistical analysis}

We estimated a sample size of 1400 children to give a $5 \%$ type 1 error and $80 \%$ power to detect a reduction in the prevalence of kwashiorkor from $4 \%$ to $1.3 \%$, assuming a dropout rate of $10 \%$. The code for the letter designation of the powder (antioxidant or placebo) was held by the manufacturer and not available to any members of the study team until clinical follow-up was complete and all data had been entered, checked, and sealed in an electronic database. We used intention to treat analysis. We assessed the difference in the primary outcome, development of kwashiorkor, between the two groups by mathematical modelling using generalised estimating equations extension of logistic regression (SAS, version 9, Cary, North Carolina). ${ }^{21}{ }^{22}$ This statistical method accounts for the clustering of participants by family and village as well as for the effect of the covariates of age and anthropometric indices. The result can be expressed as a relative risk with $95 \%$ confidence interval. We used Student's $t$ test to compare secondary outcomes and the Wilcoxon rank sum test to compare days of fever, cough, and diarrhoea between the two groups.

\section{Results}

We randomly assigned 2372 children from 2156 households to receive antioxidant powder $(n=1184)$ or placebo $(n=1188$; figure). We observed no adverse events in either group. Forty (1.7\%) children were lost to follow-up. Dropout rates were equally distributed for both groups, and 28 (70\%) of those who were lost to follow-up were children who moved from the geographical area of the study (figure). The demographic and nutritional characteristics of the children who dropped out were similar to those who completed the study. The demographic and nutritional characteristics of the children on enrolment were similar for both groups (table 1).

Of the 2372 children enrolled in the study, 62 (2.6\%) developed oedema; 39/1184 (3.3\%) of these children received antioxidants and 23/1188 (1.9\%) received placebo (relative risk $1.70,95 \%$ confidence interval 0.98 to 2.42 ). No siblings were found to have kwashiorkor. Seven children died from illness or injury without oedema, three in the antioxidant supplement group and four in the placebo group. Secondary outcomes did not differ significantly (table 2), including rates of weight and 


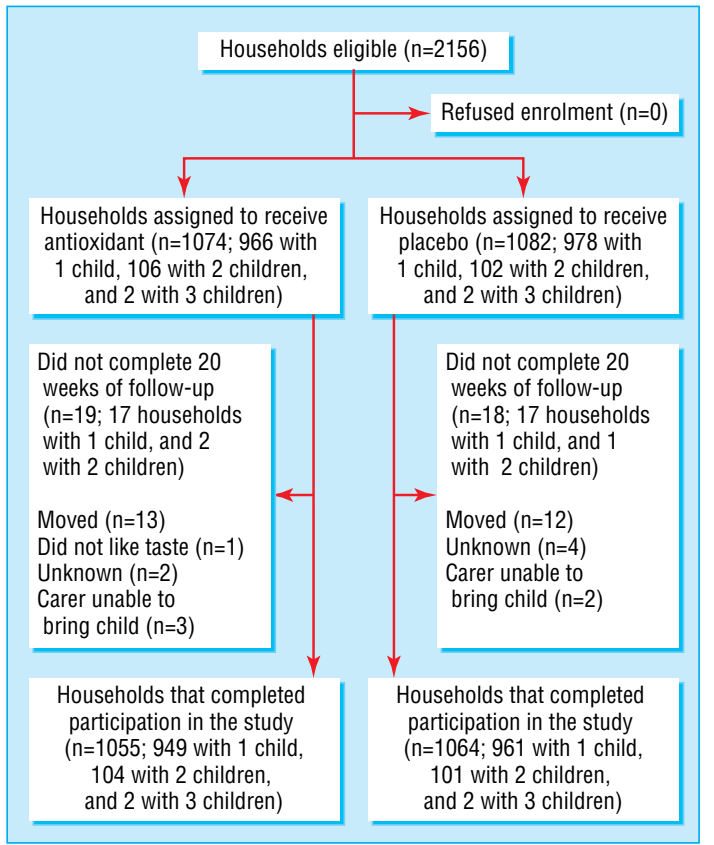

Flow of participants through the trial

height gain and the number of days of fever, cough, and diarrhoea.

Children who developed oedema were younger and had significantly lower anthropometric indices than those who did not (table 3). Children who developed oedema reported a larger fraction of days with fever in the 14 days before oedema appeared than children who did not $(5.5 \%$ v 2.4\%; difference $3.1 \%, 2.9 \%$ to $3.3 \%)$, as well as more cough $(2.7 \% v 1.8 \% ; 0.9 \%$, $0.6 \%$ to $1.2 \%)$ and diarrhoea ( $5.8 \%$ v $2.0 \% ; 3.8 \%, 3.4 \%$ to $4.2 \%)$.

We collected 45 urine specimens, 21 from children with oedema and 24 from children without oedema. All 30 children who received the antioxidant supplement tested positive for fluorescence (100\%, 88\% to $100 \%)$. All 15 children assigned to receiving placebo tested negative for fluorescence.

Of the 62 children who developed oedema, 60 received the home based treatment with ready to use therapeutic food and

Table 1 Baseline characteristics of the 2372 randomised participants, according to group assignment

\begin{tabular}{lcc} 
Characteristics & $\begin{array}{c}\text { Antioxidant supplementation } \\
(\mathbf{n}=\mathbf{1 1 8 4})\end{array}$ & Placebo (n=1188) \\
\hline No (\%) of boys & $578(49)$ & $576(49)$ \\
\hline Mean (SD) age in months & $28.2(10.6)$ & $28.5(10.4)$ \\
\hline Mean (SD) weight for age z score & $-1.4(1.0)$ & $-1.4(1.0)$ \\
\hline Mean (SD) height for age z score & $-1.7(1.3)$ & $-1.6(1.3)$ \\
\hline $\begin{array}{l}\text { Mean (SD) weight for height z } \\
\text { score }\end{array}$ & $-0.5(0.9)$ & $-0.5(0.9)$ \\
\hline $\begin{array}{l}\text { Mean (SD) circumference of middle } \\
\text { upper arm in cm }\end{array}$ & $14.8(1.3)$ & $14.8(1.3)$ \\
\hline $\begin{array}{l}\text { No (\%) of children still breast } \\
\text { feeding }\end{array}$ & $477(40)$ & $450(38)$ \\
\hline $\begin{array}{l}\text { Mean (SD) age when breast } \\
\text { feeding was stopped in months }\end{array}$ & $23.6(6.2)$ & $24.0(5.9)$ \\
\hline $\begin{array}{l}\text { No (\%) of children whose mother } \\
\text { is alive }\end{array}$ & $1180(100)$ & $1183(100)$ \\
\hline $\begin{array}{l}\text { No }(\%) \text { of children whose father is } \\
\text { alive }\end{array}$ & $1145(97)$ & $1153(97)$ \\
\hline No (\%) with access to clean water & $636(54)$ & $1123(95)$ \\
\hline $\begin{array}{l}\text { No (\%) of children in whose } \\
\text { houses grass was used as a } \\
\text { roofing material }\end{array}$ & $1125(95)$ \\
\hline
\end{tabular}

Table 2 Secondary outcomes (by intention to treat) in children receiving antioxidant supplementation or placebo

\begin{tabular}{|c|c|c|c|}
\hline & $\begin{array}{c}\text { Antioxidant } \\
\text { supplementation } \\
(\mathrm{n}=1184)\end{array}$ & $\begin{array}{l}\text { Placebo } \\
(n=1188)\end{array}$ & Difference $(95 \% \mathrm{Cl})$ \\
\hline $\begin{array}{l}\text { Mean (SD) weight gain } \\
\text { during } 20 \text { weeks in } \\
\text { g/kg/day }\end{array}$ & $0.5(0.5)$ & $0.5(0.4)$ & $0.0(-0.1$ to 0.1$)$ \\
\hline $\begin{array}{l}\text { Mean (SD) height gain } \\
\text { during } 20 \text { weeks in } \\
\mathrm{mm} / \text { day }\end{array}$ & $0.2(0.2)$ & $0.2(0.3)$ & $0.0(-0.1$ to 0.1$)$ \\
\hline $\begin{array}{l}\text { Mean (SD) gain in } \\
\text { circumference of the } \\
\text { middle upper arm } \\
\text { during } 20 \text { weeks in } \\
\text { mm/day }\end{array}$ & $0.0(0.1)$ & $0.0(0.1)$ & $0.0(-0.1$ to 0.1$)$ \\
\hline No $(\%)$ of days of cough & $3142(1.9)$ & $2899(1.8)$ & $0.1 \%(0.0$ to 0.2$)$ \\
\hline No $(\%)$ of days of fever & $4099(2.5)$ & $3982(2.4)$ & $0.1 \%(0.0$ to 0.2$)$ \\
\hline $\begin{array}{l}\text { No (\%) of days of } \\
\text { diarrhoea }\end{array}$ & $3410(2.1)$ & $3372(2.1)$ & $0.0 \% \quad(-0.1$ to 0.1$)$ \\
\hline $\begin{array}{l}\text { Mean (SD) final weight } \\
\text { for age } z \text { score }\end{array}$ & $-1.4(1.0)$ & $-1.4(1.0)$ & $0.0(-0.1$ to 0.1$)$ \\
\hline $\begin{array}{l}\text { Mean (SD) final height } \\
\text { for age } z \text { score }\end{array}$ & $-1.8(1.2)$ & $-1.8(1.2)$ & $0.0(-0.1$ to 0.1$)$ \\
\hline $\begin{array}{l}\text { Mean (SD) final weight } \\
\text { for height } z \text { score }\end{array}$ & $-0.4(0.8)$ & $-0.4(0.8)$ & $0.0(-0.1$ to 0.1$)$ \\
\hline
\end{tabular}

two were brought to a nutritional rehabilitation unit. Sixty one children subsequently recovered.

\section{Discussion}

Supplementation with riboflavin, vitamin E, selenium, and $\mathrm{N}$-acetylcysteine at a level of three times the recommended dietary allowance did not prevent kwashiorkor in a susceptible population, nor was it associated with better growth or less fever, cough, or diarrhoea.

\section{Advantages of the study design}

The study design ensured that the two groups were similar in every characteristic other than the type of supplement they received. The actual sample size was much larger than planned because we had underestimated the populations of the participating villages. This study population represents rural African children who develop kwashiorkor around the time they are weaned from the breast. It may not be representative of other children at risk of developing kwashiorkor. HIV rates, for example, are likely to be much lower in this population than in urban African populations. Children under 12 months were not enrolled, and the results should therefore not be extrapolated to infants.

Table 3 Comparison of demographic and nutritional characteristics at enrolment of children who developed oedema and children who did not develop oedema

\begin{tabular}{lccc} 
Characteristics & $\begin{array}{c}\text { Oedema } \\
\mathbf{( n = 6 2 )}\end{array}$ & $\begin{array}{c}\text { No oedema } \\
\mathbf{( n = 2 3 1 0 )}\end{array}$ & Difference (95\% Cl) \\
\hline No (\%) of boys & $26(42)$ & $1128(49)$ & $7 \%(-6$ to 20) \\
\hline Mean (SD) age in months & $19.8(7.7)$ & $28.6(10.5)$ & $8.8(6.2$ to 11.4$)$ \\
\hline $\begin{array}{l}\text { Mean (SD) weight for age } \\
\text { z score }\end{array}$ & $-2.0(1.1)$ & $-1.4(1.0)$ & $0.6(0.3$ to 0.9$)$ \\
\hline $\begin{array}{l}\text { Mean (SD) height for age } \\
\text { z score }\end{array}$ & $-2.0(1.3)$ & $-1.6(1.3)$ & $0.4(0.1$ to 0.7$)$ \\
$\begin{array}{l}\text { Mean (SD) weight for } \\
\text { height z score }\end{array}$ & $-1.0(1.0)$ & $-0.5(0.9)$ & $0.5(0.3$ to 0.7$)$ \\
\hline $\begin{array}{l}\text { No (\%)of children whose } \\
\text { mother is alive }\end{array}$ & $61(98)$ & $2302(100)$ & $1 \%$ \\
\hline $\begin{array}{l}\text { No }(\%) \text { of children whose } \\
\text { father is alive }\end{array}$ & $60(97)$ & $2238(97)$ & 0 \\
\hline
\end{tabular}




\section{Role of HIV infection}

HIV infection predisposes children to develop severe malnutrition, although this is more commonly manifest as marasmus than kwashiorkor. Among a population of underweight rural Malawian children in an adjoining district aged 2-4 years, $1 \%$ were infected with HIV. ${ }^{23}$ Therefore, if we assume that among our population of healthy children the prevalence of HIV infection was $0.5 \%$, then about $12 \mathrm{HIV}$ infected children would have participated in our study. Although it is likely that a few of the children who developed kwashiorkor in this study were infected with HIV, this represents less than $20 \%$ of the 62 cases of kwashiorkor.

\section{Oedema as a clinical sign}

In Malawi, oedema is a common complaint at health centres and hospitals, and more than $98 \%$ of it is the result of kwashiorkor. ${ }^{24}$ The children in this study who developed oedema did not have pallor of their conjunctiva or clinical evidence of severe anaemia. The study team gained the impression that many of the children found to have oedema had associated findings suggestive of kwashiorkor, such as hair discoloration and dermatosis, and their oedema resolved with nutritional therapy. This evidence shows that the oedema seen in this study was the result of kwashiorkor.

\section{Compliance}

It was not possible for study staff directly to observe children taking the powder daily, but the small subset of children who had urine tested for excess riboflavin, which was present in the antioxidant powder but not the placebo, indicated that compliance was excellent. Children showed enthusiasm at their appointments to collect their powder bottles, and mothers did not report that their children were reluctant to drink the supplement. The health surveillance assistants provided regular encouragement and reminders to mothers to comply. This evidence indicates that compliance was high.

\section{Role of antioxidants in preventing kwashiorkor}

The "negative" results of this study made us speculate if a larger antioxidant dose is needed to prevent kwashiorkor. The dose of antioxidants given in this study corresponded to an amount three times greater than the recommended dietary allowance, and the supplement was taken in addition to their habitual diet. Children should therefore have received enough of these dietary antioxidants to fulfil their dietary requirements. If larger doses of this antioxidant supplementation were able to prevent kwashiorkor a trend should have emerged of fewer cases of kwashiorkor in the children receiving antioxidants, rather than more cases as was observed here.

\section{Meaning of findings}

Our findings are remarkable in light of the previously described associations between kwashiorkor and deficiency in essential antioxidants such as vitamin $\mathrm{E},{ }^{9}$ selenium, ${ }^{10}$ and glutathione ${ }^{8}$ and evidence of having excessive oxidative stress. ${ }^{12}$ These previous studies were comparisons of biochemical variables in small groups of severely ill, malnourished children who had been admitted to hospital. Our study was a prospective trial investigating the role of antioxidants in the aetiology of kwashiorkor and indicates that antioxidant depletion may be a consequence rather than a cause of kwashiorkor.

\section{Kwashiorkor and environmental factors}

Environment, particularly diet, certainly has an important role in the pathogenesis of kwashiorkor; the condition is not seen in children with an adequate nutritional intake. Intrinsic characteristics of the host may also be required for the development of kwashiorkor. It is possible variant isozymes or variations in con-

\section{What is already known about this topic}

Kwashiorkor is associated with increased oxidative stress and an inadequate diet in poor populations in the developing world

Because of this association, depletion of antioxidants has been postulated as the cause of kwashiorkor

\section{What this study adds}

Supplementation with riboflavin, vitamin E, selenium, and $\mathrm{N}$-acetylcysteine at a level of three times the recommended dietary allowance did not prevent kwashiorkor in a susceptible population

Supplementation with these antioxidants was not associated with better growth or less fever, cough, or diarrhoea

centrations of enzymes in the metabolic pathways permit the development of kwashiorkor in children with poor diets. Differences in the pattern of amino acid concentrations between children with kwashiorkor and marasmus have been used to propose this. ${ }^{25}$ In addition to dietary and nutritional investigations, genetic mapping techniques to delineate host factors may prove useful to unravelling the enigma of kwashiorkor.

Contributors: MM, HC, and MC designed the study, enrolled and followed the children, analysed the data, and wrote the manuscript. $\mathrm{AB}$ planned the study, developed the formulation of antioxidant supplement, and reviewed the manuscript. PA planned the study in accordance with the Good Clinical Practice guidelines and reviewed the manuscript. DB designed the study, analysed the data, and reviewed the manuscript. MM is guarantor.

Funding: This work was supported by the Cooperative Agreement 58-6250-6001 from the United States Department of Agriculture/ Agricultural Research Service and the Allen Foundation. The sponsors of the study had no role in study design, data collection, data analysis, data interpretation, or writing of the report.

Competing interests: None declared.

Ethical approval: The trial was approved by the research ethics committees of Washington University School of Medicine in St Louis, MO, and by the College of Medicine, University of Malawi in Blantyre, Malawi.

1 Williams CD. Kwashiorkor a nutritional disease of children associated with a maize diet. Lancet 1935;2:1151-2.

Wellcome Trust Working Party. Classification of infantile malnutrition. Lancet 1970;2:302-3.

3 Waterlow JC. Kwashiorkor revisited: the pathogenesis of oedema in kwashiorkor and its significance. Trans R Soc Trop Med Hyg 1984;78:436-41.

4 Golden MHN, Golden BE, Jackson AA. Albumin and nutritional oedema. Lancet $1980 ; 1: 114-6$

5 Gopalan C. Kwashiorkor and marasmus: evolution and distinguishing features. In: Calorie deficiencies and protein deficiencies, McCance RA, Widdowson ES, eds. London: Churchill, 1968.

6 Golden MHN. Protein deficiency, energy deficiency, and oedema of malnutrition. Lancet 1982;1:1261-5.

7 Golden MHN, Ramdath D. Free radicals in the pathogenesis of kwashiorkor. Proc Nutr Soc 1987;46:53-68.

8 Jackson AA. Blood glutathione in severe malnutrition in childhood. Trans R Soc Trop Med Hyg 1986;80:911-3.

9 Sive AA, Subotzky EF, Malan H, Dempster WS, De V, Heese H. Red blood cell antioxidant enzyme concentrations in kwashiorkor and marasmus. Ann Trop Paediatr 1993;13:33-8.

10 Becker K, Bötticher D, Leichsenring M. Antioxidant vitamins in malnourished Nigerian children. Int J Vitam Nutr Res 1994;64:306-10.

11 Lenhartz H, Ndasi R, Anninos A, Botticher D, Mayatepek E, Tetanye E, et al. The clinical manifestation of the kwashiorkor syndrome is related to increased lipid peroxidation.J Pediatr 1998;132:879-81.

12 Manary MJ, Leeuwenburgh C, Heinecke JW. Increased oxidative stress in kwashiorkor. J Pediatr 2000;137:421-424.

13 Badaloo A, Reid M, Forrester T, Heird WC, Jahoor F. Cysteine supplementation improves the erythrocyte glutathione synthesis rate in children with severe edematous improves the erythrocyte glutathione synthesi
malnutrition. Am J Clin Nutr 2002;76:646-52.

14 Courtright P, Canner J. The distribution of kwashiorkor in the southern region of Malawi. Ann Trop Paediatr 1995;15:221-6.

15 European Parliament. Directive 2001/20/EC of the European parliament and of the council of 04 April 2001 on the approximation of the laws, regulations and administra- 
tive provisions of the member states relating to the implementation of good clinical practice in the conduct of clinical trials on medicinal products for human use. Official J Eur Communities 2001;121:34-44.

16 Campbell MK, Elbourne DR, Altman DG. CONSORT statement: extension to cluster randomized trials. BMJ 2004;328:702-8.

17 Institute of Medicine. Dietary reference intakes for thiamine, riboflavin, niacin, vitamin B6, folate, vitamin B12, pantothenic acid, biotin, and choline. Washington, DC: National Academy Press, 1998.

18 Institute of Medicine. Dietary reference intakes for vitamin C, vitamin E, selenium, and carotenoids. Washington, DC: National Academy Press, 2000.

19 Manary MJ, Ndekha MJ, Ashorn P, Maleta K, Briend A. Home-based therapy for severe malnutrition with ready-to-use food. Arch Dis Child 2004;89:557-61.

20 Jones HI. Riboflavine as an indicator of drug taking behaviour. Med J Aust Jones HI. Ribon.

21 Klar N, Donner A. Current and future challenges in the design and analysis of cluster randomization trials. Stat Med 2001;20:3729-40.

22 Lipsitz SH, Kim K, and Zhao L. Analysis of repeated categorical data using generalized estimating equations. Stat Med 1994;13:1149-63.

23 Maleta K, Kuittinen J, Duggan MB, Briend A, Manary M, Wales J, et al. Supplementary feeding of underweight, stunted Malawian children with a ready-to-use food. J Pediatr Gastroenterol Nutr 2004;38:152-8.

24 Medical Council of Malawi. Standard treatment for common illnesses of children in Malawi. Lilongwe: Medical Council of Malawi, 1992

25 Phadke MA, Khedkar VA, Pashankar D, Kate SL, Mokashi GD, Gambhir PS, et al. Serum amino acids and genesis of protein energy malnutrition. Indian Pediatr 1995;32:301-6.
(Accepted 15 March 2005)

doi $10.1136 /$ bmj.38427.404259.8F

Department of Pediatrics, Washington University School of Medicine, St Louis Children's Hospital, One Children's Place, St Louis, MO 63110, USA

Heather Ciliberto medical student

Michael Ciliberto medical student

Institut de Recherche pour le Développement, 276 rue Lafayette, 75010 Paris, France

Andr Briend research scientist

Paediatric Research Centre, Tampere University Hospital, PO Box 2000 ,

FIN-33521, Tampere, Finland

Per Ashorn professor

Department of Pediatrics, Children's Nutrition Research Center, Baylor College of Medicine, Houston, TX 77030-2600, USA

Dennis Bier professor

Mark Manary adjunct associate professor

Correspondence to M Manary manary@kids.wustl.edu 